\title{
Forest Crime in Africa: Actors, Markets and Complexities
}

\author{
Eric M. Kioko
}

\section{1 Introduction}

According to the United Nations Office on Drugs and Crime (UNODC), forest crime refers to the illegal exploitation of the world's flora, which includes taking, trading (supplying, selling or trafficking), importing, exporting, processing, possessing, obtaining and consuming wild flora in contravention of national or international law. ${ }^{1}$ Forest crime is on the rise across the globe, but particularly in poor tropical countries. The FAO's Global Forest Resources Assessment report of 2020 notes that Africa had the largest annual rate of net forest loss in 2010-20 at 3.9 million hectares, followed by South America at 2.6 million hectares. Forests in West, central, East, and southern Africa are particularly vulnerable to the illicit exploitation of high-demand endangered trees, thus putting biodiversity, local economies, and humans at great risk.

In 2016, the United Nations Environment Programme (UNEP) and the International Police Organization (INTERPOL) estimated the annual monetary value of forestry crimes worldwide at US $\$ 51-5^{2}$ billion, and of the illegal wildlife trade at US $\$ 7-23$ billion (Nellemann et al. 2016). Based on these estimates, forest crime has surpassed poaching and other forms of illegal trade in wildlife by an overwhelming margin to become the world's leading environmental crime. ${ }^{2}$ Despite its spectacular increase, forest crime has received surprisingly little attention in the media and in scientific and crime reports compared with the illegal trade in wildlife. A review of recent studies on environmental crimes in Africa reveals an almost exclusive focus on wildlife poaching and on the illicit trade in ivory (Coutu et al. 2016; Harrison et al. 2015; Titeca 2019; Varun et al. 2014; Weru 2016). Reports featuring forest crime (Bussmann 1996; Müller and Mburu 2009; Nellemann and Interpol 2012) tend to give a rather general

1 https://www.unodc.org/unodc/en/wildlife-and-forest-crime/overview.html.

2 The term 'environmental crime' covers illegal activities, including serious and transnationally organized crimes, that harm the environment and from which individuals, groups or companies benefit through exploiting, damaging, trading in or stealing natural resources (Nellemann et al. 2016: 17).

(C) ERIC M. KIOKO, 2022 | DOI:10.1163/9789004471641_011 
picture of illegal timber logging and to lack proper empirical analysis of the organization and execution of the criminal behaviour.

African sandalwood (Osyris lanceolate) is a high value plant used globally in the manufacture of perfumes, cosmetics, and pharmaceuticals. Its recent commodification and commercial exploitation follows a decline in the global supply from India and Australia (Arun Kumar et al. 2012), coupled with what appears to be a rising demand for authentic, naturally occurring species (Kioko forthcoming). African rosewood (Guibourtia coleosperma), extracted mostly from West Africa, but also from central and southern Africa, is a strong, heavy brownish wood with dark veining popular for making luxury furniture and musical instruments. The International Union for Conservation of Nature (IUCN) includes both sandalwood and rosewood in its red list of threatened species, as does the CITES $^{3}$ multilateral treaty to protect endangered plants and animals from unregulated and illegal exploitation.

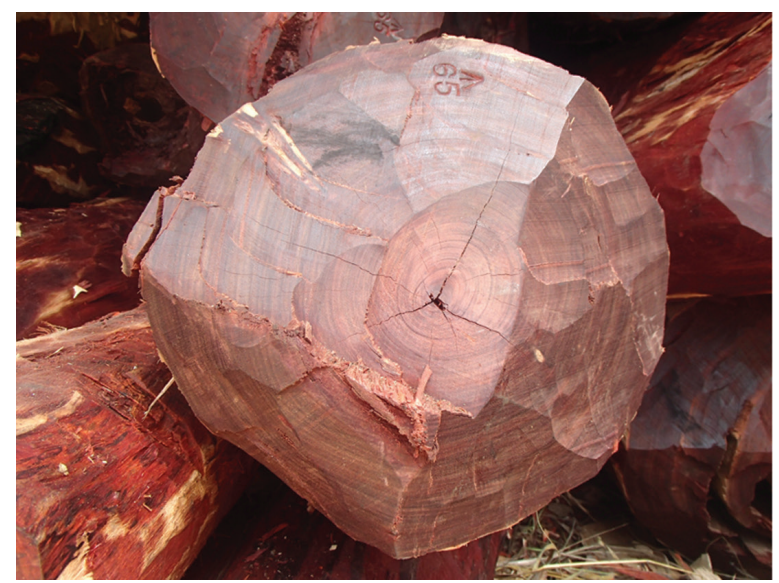

FIGURE 1 Rosewood CIFOR/ PAOLO OMAR CERUTTI 2020

Mainly due to the absence of reliable and timely data, complex supply chains, weak legislation and a lack of international cooperation, it is difficult to obtain accurate statistics on illegal forest activities in Africa. It is even more difficult to

3 Cites (the Convention on International Trade in Endangered Species of Wild Fauna and Flora) is an international agreement between governments to ensure that international trade in specimens of wild animals and plants does not threaten their survival (source: https:// cites.org/eng/disc/what.php). 

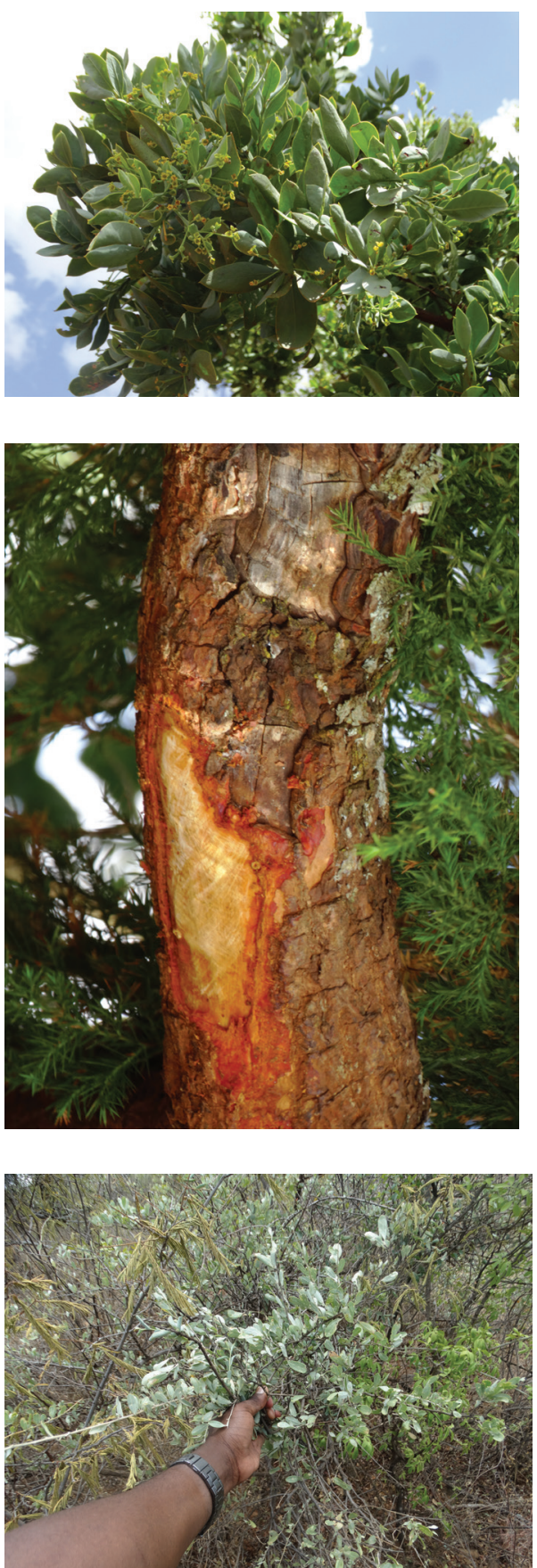

FIGURE 2 East Africa's sandalwood

PHOTOS BY ERIC KIOKO 2019 
quantify what specific plants have been illegally obtained and traded because of an incapacity among affected states to carry out species-specific surveillance, the difficulty of distinguishing between legally and illegally obtained and traded forest products, weak forest governance across states, the complicity of public officials in forest crime syndicates, and a lack of export data from customs.

However, some rough estimates exist. The 2017 Trade Records Analysis of Flora and Fauna in Commerce notes that the export of illicit timber (in the form of logs and sawn wood) to China from Mozambique has seen a sevenfold increase in the last ten years (Lukumbuzya and Sianga 2017). Furthermore, the authors note that the DRC has experienced exponential growth in the timber trade since the 200os. It is now among the top ten African countries exporting timber to the Chinese market, with about $30-50$ per cent of imports between 2014 and 2017, while Tanzania's export permits indicated that more than 90 per cent of natural forest timber (around 12,0oo cubic metres) is destined for China. The 2016 UNEP and INTERPOL report estimates that Kenya loses 70,000 hectares of forest each year to illegal logging. ${ }^{4}$ Zambia exports substantial volumes of logs and sawn wood to the DRC, South Africa and China (European Commission 2013). The illegally obtained and traded species from these countries are listed in the IUCN red list. However, as noted earlier, the volumes of exports for illicit sandalwood and rosewood, or any other individual species, is rather difficult to determine with precision.

While the precise estimates remain elusive, there is a consensus among scholars and concerned agencies that forest crimes are on the rise due to a number of factors, including the growing demand for industrial wood, fuelwood, and fragrant-scented wood. Sloan and Sayer (2015) note that the rising demand for wood is principally in poorer countries, and growth in demand will accelerate into the future, particularly in the Asia-Pacific region.

\subsection{Sandalwood}

Commercial exploitation of East Africa's sandalwood may be traced back to the early 19oos (Mwang'ingo et al. 2003). However, the indiscriminate extraction and massive smuggling of the precious wood has been occurring since 2000 and peaked in 2017. Extraction concentrated on communally owned lands (community conservation areas) and state protected forests. The scale of exploitation and wanton plunder of natural resources prompted Kenya and Tanzania to ban the sandalwood trade in 2005 and 2007 respectively, but the

\footnotetext{
4 https://www.voanews.com/africa/report-kenya-losing-forests-organized-crime.
} 
ban has proven hard to enforce and therefore the illicit trade persists through a dynamic and increasingly resilient transnationally organized criminal group. ${ }^{5}$ Following Uganda's reluctance to restrict the sandalwood trade, syndicate members shifted their operations from Tanzania and Kenya to Tororo, Uganda, making it the nerve centre for laundering illegally obtained sandalwood before export to the Chinese and Indian markets via the Kenyan and Tanzanian ports (Kioko forthcoming).

The key players of domestic, regional and global supply chains of sandalwood include loggers from local communities, smugglers/traders, transporters, and buyers from India and China. Smugglers purchase raw sandalwood from community conservancies at between 80 and 200 Kenyan Shillings (US\$ 0.74-1.84) a kilogramme and sell it to Chinese and Indian syndicate members in Tororo for between 800 and 1200 Kenyan Shillings (US \$ 7.34-11.03), thereby making roughly US $\$ 100,000$ for every 14-ton truckload of sandalwood. Based on interview data from Baringo, Mukogodo Forest (Laikipia North), and Samburu (the Mathews Range Forest) in Kenya, between 2015 and 2017 some brokers and community members turned loggers earned around 200,000 Kenyan Shillings (US\$ 1840) a month from the sale of sandalwood from community conservancies to smugglers.

The bribes smugglers paid to members of the syndicate, usually local administrators, police officers, judges, and members of the council of elders, were in the region of between ten thousand and a million Kenyan Shillings (US\$ 92-9200) depending on their position, influence, and role in facilitating the illegal trade. Consequently, the illicit trade in sandalwood turned smugglers, loggers, and some public officials into millionaires overnight. The response to increased interagency surveillance of those engaged in the illicit operations has been to become more sophisticated, to adopt more innovative means of transport such as luxury vehicles, and to hire corrupt police officers to transport the sandalwood in government trucks to disguise their contents. ${ }^{6}$

The organized syndicate of people engaged in smuggling sandalwood in East Africa is recruited from a network of state and non-state actors who are selected because their role, power, or influence in society or government is likely to guarantee the success of the criminal enterprise. Notably, some corrupt public officials constitute important nodes for the criminal enterprise.

5 Organized criminal groups consist of three or more people working together over a period of time, with a view to committing one or more serious crimes to generate financial or material benefits, often by providing illicit goods and services (UNODC 2020: 19).

6 https://www.standardmedia.co.ke/ktnnews/ktn-newsdesk/video/2000100743/police-vehii cle-nabbed-smuggling-sandalwood-worth-sh2o-million-in-nakuru. 


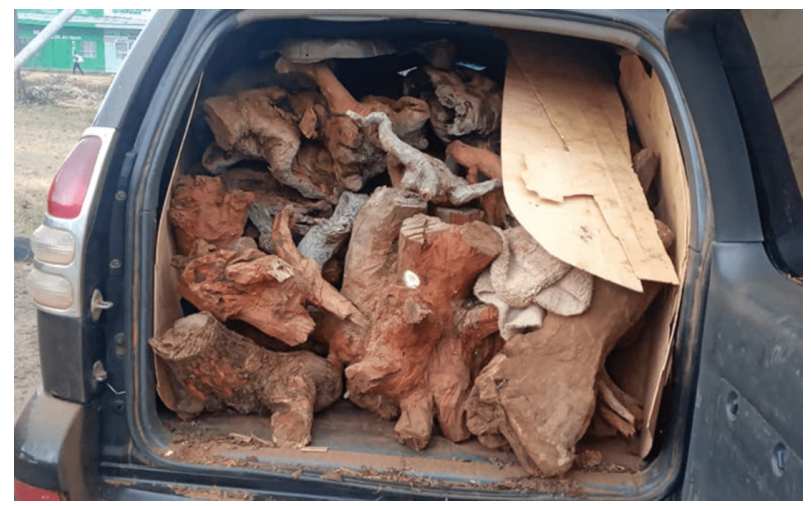

FIGURE 3 Luxury vehicle impounded by police in Samburu County ferrying sandalwood worth 2.5 million Kenyan Shillings (US\$23,00o) CITIZEN DIGITAL, JANUARY 29, 2020

Interviews with sandalwood smugglers in the Kenya-Uganda border town of Malaba show that they see themselves as ordinary business people filling a critical gap in the demand and supply of goods and services. Although mostly high-school or college dropouts, by being in a position to buy the loyalty and legitimacy of state officials, many of these smugglers have over time become extremely rich. Their allegiance to each other is rooted in their working history, where they tap into pre-existing relations involving illicit activities, but also tend to have roots in a single shared ethnic descent, which may create some level of trust. According to the UNODC (2009:12), these organized criminal groups take the form of shifting alliances of loose, flexible networks of key individuals operating at national, regional, and international levels. In East Africa, for instance, the criminal groups include individuals from West Africa, Asia and Europe.

The extraction of sandalwood is mainly done by uprooting the whole tree to obtain the heartwood and roots where the greatest intensity of aroma and essential oils are to be found. The extraction process leaves behind a landscape dotted with open pits and causes extensive damage to the surrounding flora, including the destruction of the wildlife habitat. Community participation in illicit value chains, particularly inside community-based conservancies, deserves close attention. Organized criminal groups are increasingly exploiting local situations, such as poverty, intergroup conflicts, and weak indigenous nature-conservation norms and rules to profit from communally held resources, and thereby threatening the decentralized model of conservation. The situation may lead to the 'empty forest syndrome' exemplified in much of Malaysia and Thailand where forests have been stripped off all their 'valuable' timber and wildlife (Redford 1992). 


\section{$2.2 \quad$ Rosewood}

According to UNODC (2O2O), rosewood is the most trafficked wild product in the world by value and volume (see Figure 4). Rosewood, most of which is headed to China, is traded far more than elephant ivory, rhino horn, and pangolin scales combined, and is often called the 'ivory of the forest' (Ong and Carver 2019). From the figure below, which shows the volume of trade as calculated from the value of the respective seizures of wildlife, rosewood accounts for more than 40 per cent, which is higher than the illegal trade in elephants (33.1 per cent) and rhinos (5.5 per cent) combined.

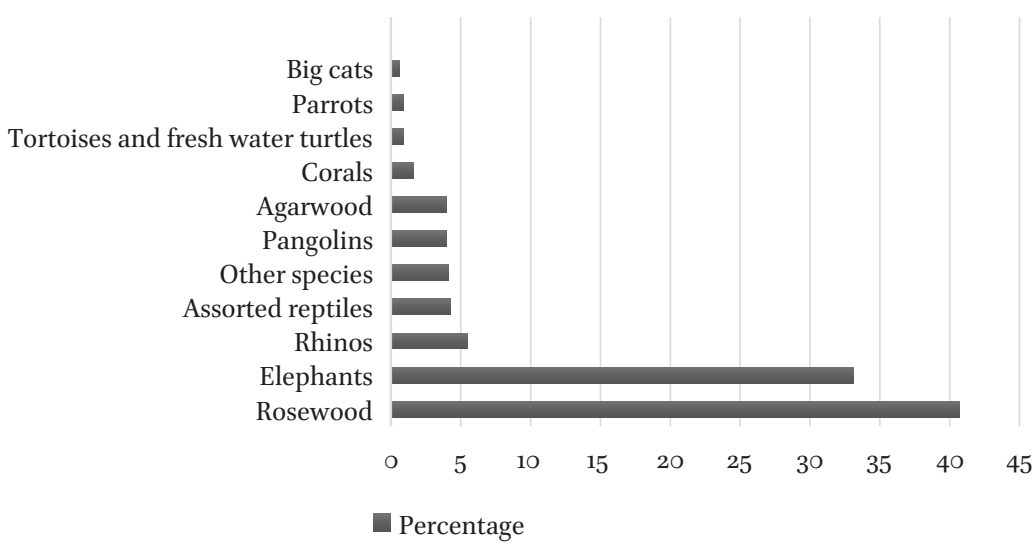

FIGURE 4 Volume of trade based on the value of seizures of respective wildlife SOURCE: MODIFIED FROM UNODC (2020: 11)

The largest flow of illicitly harvested rosewood between 2017 and 2020 came out of Africa, with more rosewood exported after it was listed in the 2017 CITES, with Nigeria alone exporting 750,00o cubic metres in 2017. This is equivalent to about four million trees, or over 30,00o shipping containers, an average of almost one hundred container loads exported per day (UNODC 2020: 13). Africa is estimated to be losing US\$ 17 billion in revenue annually as a result of the illegal trade. ${ }^{7}$ In 2014, China imported rosewood logs from West Africa to the value of US\$2.5 billion, which meant that at least one tree was logged every minute. ${ }^{8}$ Ghana, which is considered one of the main transit countries, exported 540,000 tons - the equivalent of 23,478 twenty-foot containers or approximately six million trees - of illegal rosewood to China between 2012

7 https://allafrica.com/stories/201907310048.html.

8 https://www.clientearth.org/race-rosewood-china-toll-west-africas-forests/. 
and 2019. ${ }^{9}$ The US-based Environmental Investigation Agency (EIA) indicates that over 933 o tons of rosewood, worth over US $\$ 5.4$ million, was exported to China in the month of September 2019. ${ }^{10}$

In southern Africa, the Kavango-Zambezi Transfrontier Conservation Area (KAZA) also comes into focus with reference to the illicit trade in rosewood (see Cerutti 2020; Nott et al. 2020). Cerutti notes that about US $\$ 9.0$ billion dollars worth of rosewood was imported into China over the last decade with Zambia being the main transit country. In a related study, a team from the Centre for International Forestry Research estimated the cost of bribes paid annually on the roads and border points of Zambia at about US 1.7 million (Cerutti et al. 2018: 56). Illicit trade in rosewood is also prevalent in Namibia. In February 2020, The Namibian reported that from November 2018 until December 2019, nearly 70,00o tons of timber were exported through the port of Walvis Bay, 13 per cent of which was mostly Namibian rosewood while the rest came from Zambia, the DRC, and Angola - all destined to China, Vietnam, and smaller quantities to Saudi Arabia, Germany, and Greece. ${ }^{11}$

Despite various national and international laws and treaties having outlawed the rosewood trade, the illicit enterprise persists, and its scale will increase in the future as China's timber and forest product imports are expected to increase from an estimated 194 million cubic metres in 2015 to 254 million cubic metres by $2025 .{ }^{12}$ Ong and Carver (2019) observe that rosewood logging causes problems that go well beyond the removal of rare tree species. For example, in West Africa, it can dry out forests and leave them vulnerable to fires and desertification, while in Madagascar, tall rosewood trees serve as key nesting areas for endemic animals such as ruffed lemurs.

\section{3}

\section{The Elephant in the Room: Complexities in Addressing Forest Crimes}

There is overwhelming evidence on the drivers of environmental crimes as well as recommendations to address and control illicit enterprises (Hayman and Brack 2002; Kamweti et al. 2009; Kleinschmit et al. 2016; Varun et al. 2014;

9 https://www.bbc.com/news/world-africa-49165636; https://eia-global.org/blog-posts/2020 o721-ghana-can-end-destruction-of-illegal-rosewood-trade.

10 https://eia-global.org/press-releases/20191104-rosewood-revealed-website-launch.

11 https://www.namibian.com.na/197573/archive-read/Namibia-to-export-120-ooo-logs-oftimber.

12 https://www.risiinfo.com/press-release/chinas-timber-and-forest-products-importsexpected-to-increase-by-6o-million-cubic-meters-by-2025/. 
World Bank 2019). The drivers may be categorized into economic, social, political, and environmental, while approaches to controlling environmental crimes broadly fall under governance, including legislation and enforcement, international coordination and cooperation, political goodwill, and institutional building and strengthening. Now that we seem to know the problem and how to address it, what explains the pitiful success in addressing environmental crimes? Various difficulties characterize their mitigation in Africa, and these have great implications for the future of illicit value chains linked to forests.

\subsection{Disproportionate Attention to Wildlife and Forest Crimes}

Wildlife crimes like ivory poaching have historically attracted more attention from the media and concerned agencies than crimes associated with forests and this pattern is similar elsewhere in the world. A World Bank study on illegal logging in Brazil, Mexico, Indonesia, and the Philippines found that the cumulative probability of an illegal logging crime being penalized is less than o.082 per cent (Goncalves et al. 2012: 5). According to the report, lack of coordination among the actors in question, competing priorities, limited resources, lack of capacity, and benign and malicious neglect hamper forest law enforcement in these countries and make it an ineffective tool for countering and deterring illegal logging.

On the contrary, states have come up with legislation that imposes punitive measures on perpetrators of crimes against wild animals. For example, poaching and wildlife trafficking in both Kenya and Uganda carry a life imprisonment sentence. In South Africa, a rhino poacher was recently jailed for 77 years to signify the seriousness of the offence. ${ }^{13}$ Apart from prohibitions against trading in restricted forest products (for example, under the 2016 Forest Conservation and Management Act in Kenya), African countries lack a laid down strategy on how to curb national and transnational forest crimes let alone prosecute the offenders. Where forests crimes are punished, offenders get a reasonably light sentence. In Kenya, for instance, the jail term is between six months and five years with the option to pay a fine.

The Southern African Development Community (SADC) is no different. According to the African Forest Forum (Sola 2011), forest legislation in the region is weak, sometimes outdated, poorly structured, and contradictory. The decentralization of forest management has also been a major cause of poor enforcement where legal pluralism creates the opportunity for too many competing institutions. Illegal trade in forest products in the region

13 https://www.bbc.com/news/world-africa-28441261. 
exploits these weaknesses, including the prevailing uncertainties on the best approaches to control the vices. As is the case in the East African Community (EAC), forest offences receive relatively less attention than crimes against wild animals.

\subsection{Communication and Limits to Cooperation in Enforcement}

To set the stage for legislation and collaboration on a broad range of global environmental challenges that span international borders, states have ratified numerous international conventions and treaties on environment and natural resources. Among the multilateral environmental agreements that the EAC and SADC member states have signed is CITES, which is critical given the region's strategic location for transnational organized crime. However, EAC and SADC states grapple with the legal, political, and economic challenges that threaten the needed cooperation and integration (Elhiraika et al. 2015; Makame 2012). Treaties and agreements often lack policy harmonization and contain inadequate sanctions against non-compliance. They are also prone to corruption, the untrustworthiness of some member states and political regimes, poor enforcement, ineffective public participation, and a failure to cooperate over managing transboundary ecosystems and controlling transboundary organized criminal activities.

Poor communication within a country, between the government ministries and departments responsible for enforcing the timber trade regulations, and between neighbouring countries (see Nott et al. 2020), makes it practically impossible to synchronize the laws and coordinate the measures needed to mitigate transboundary forest crimes. In the Congo Basin, weak forest governance, combined with an increasing demand for cheap, illegal products globally, has driven a sharp rise in already widespread violations of laws enacted to protect and manage forests. As the EIA ${ }^{14}$ notes, timber illegally harvested in one country may be legally imported to another because countries are not bound to enforce the forestry laws of other countries, thus echoing the situation regarding the transnational rosewood trade in the KAZA region and the illicit sandalwood trade in East Africa. Furthermore, when illegally obtained wood from Africa enters China with the 'right' documents (for example CiTES certification obtained by bribing a customs official), it becomes legal (Ong and Carver 2019).

14 https://eia-global.org/subinitiatives/congo-basin. 


\subsection{Inability to Address the Demand and Supply of Forest Products}

Attempts to control forest and other environmental crimes have focused almost exclusively on enforcement agencies targeting criminals without reducing the size of the illegal market in which they operate. Hayman and Brack (2002: 4) argue that as long as the demand and supply pressures that produce profitmaking opportunities remain, new operations will continue to enter the international market. However, there are few data on these black market operations in which the demand for illicit products is mainly driven by changing patterns of wealth and consumption (Duffy et al. 2015).

The Chinese trade embargo on ivory, which came into force in 2018 , is hailed as a major development in the war against the illicit ivory trade. However, despite rising environmentalist pressure in China, the effectiveness of the trade embargo is debatable because of its awkward position in an authoritarian regime. Moreover, there is a conspicuous absence of measures to address forest crime, particularly the imports into the country of illicitly obtained sandalwood and rosewood from Africa.

In addition, enforcement has often deterred the 'small' players in environmental crimes, leaving the main perpetrators to seek ways of manipulating the system and finding new opportunities and actors. Varun et al. (2014: $5^{8}$ ) argue that efforts at interdiction too often net only low-value individuals, and not the true beneficiaries who consign cargoes, bankroll transactions, and ultimately reap the financial rewards. Therefore, intensifying enforcement, though crucial, is ultimately an inadequate long-term strategy with which to conserve high-value species (Challender and MacMillan 2014).

\subsection{Community Facilitation of Forest Crime}

Since the 1990s, commodification of the wild within the shared resource systems of Africa only targeted wildlife tourism in East Africa, and tourism and trophy hunting in southern Africa. Forest resources, including timber, are not commodities from which conservancy members can earn an income. Recently, however, the rising demand in wood for industry, fuel, and fragrance has driven the extraction and commercial exploitation of endangered trees from conservancies and state-protected parks and forests.

Against СвNRM ideals, and in contravention of the rules, regulations, and sanctions that govern the extraction and use of shared resources, farmers and even members of some conservancies are increasingly being lured into logging, thereby facilitating a crime of international significance. The incentive for local user groups to protect shared resources and to benefit jointly from them through tourism-based activities therefore suffers a huge blow as capitalist tendencies motivate individuals to exploit community-held resources. 
Mitigating forest crimes becomes a big challenge when the socio-economic dynamics are moving in the opposite direction - notably a youth bulge compounded by unemployment and problems of generational control taking centre stage.

\subsection{Chasing Ghosts: Complicit State Officials and Enforcement Agencies}

There is overwhelming evidence of state officials being complicit in environmental crime syndicates, particularly in Africa. Maguire and Haenlein (2015) observe that highly networked organized crime groups, brokers and corrupt government officials continue to drive the illegal ivory trade across East Africa, by exploiting weak legislation and enforcement by security agencies. Corruption is cited as the main driving force behind the trends in both wildlife and forest crimes, which if left unchecked will soon lead to the extinction of specific flora and fauna. ${ }^{15}$ The illegal trade in sandalwood and rosewood thrives primarily because the public officials responsible for enforcing the law are succumbing to bribery.

Wildlife and forest resources are a political commodity (Gibson 1999), so can be exchanged for political favours. This means that politicians make decisions about how wildlife and forests are exploited. Gibson (1999) argues that politicians use wildlife to discriminate between allies and enemies: their decisions affect how individuals interact with wildlife, who owns wild animals, who hunts, when they hunt, what weapons and equipment they use, which species they kill, and how they exchange wildlife products.

Given the active role of state security agencies and powerful officials in forest crime, efforts to curb illicit transactions may only serve to show potential donors and development partners that a government is committed to the fight, but ultimately obscure the true nature of these crimes.

\section{Conclusion: the Future of Illicit Forest Value Chains in Africa}

Illegal logging and other forms of forest crime continue to receive less attention than wildlife crimes, despite the former being greater than the latter by value and volume. There is a current obsession with combating the illegal wildlife trade, including state of the art monitoring of wildlife in real time and the development of cutting edge, hi-tech tools and equipment (World Bank 2018). According to the World Bank (2016) and Global Environment Facility, ${ }^{16}$ most

15 https://www.unodc.org/unodc/en/corruption/wildlife-and-forest-crime.html.

16 https://www.thegef.org/news/gef-increases-funding-combat-illegal-wildlife-trade. 
of the international funding is channelled into combating the illegal wildlife trade. Few if any international or country-specific resources are committed to reducing transnational forest crime.

What explains this disproportionate attention and how does it affect the future of forests in Africa? This dichotomy has deep colonial roots in which forestry was always thought to be commercial while wildlife was decommodified. Unlike forest resources, wildlife was linked to class, status and prestige and restrictions forbade most Africans from game hunting (see Steinhart 2006). Peluso (1991) observes that while regulation of access to forested land in many countries began in the colonial period, postcolonial state control of forested land gained greater ideological, political and economic importance where forestry agencies lay claims on and commoditize particular forests and species to generate revenue, thereby earning themselves legitimacy from the state.

Therefore, the importance accorded to wildlife and related crimes has somewhat blinded the escalating levels of crime connected to forests across the globe. This explains the weak enforcement of forest policy and laws, lack of cooperation over combating transnational forest crimes, inability to address the demand and supply of forest products, and the thriving organized criminal networks that survive by exploiting these weaknesses. The uneven treatment of wildlife and forests poses a challenge to the future of biodiversity in Africa and across the globe. I argue that unless forest crime is given as much or more attention than wildlife crime, the effects of the indiscriminate plunder of forest products may be further reaching than those of wildlife crime. The ongoing trends, if unresolved, may potentially create a future in which forests in Africa are devoid of specific trees and wildlife.

Community facilitation of forest crimes deserves closer attention. Especially within shared resource systems, the participation of certain individuals in organized crime syndicates through the extraction of high value trees creates uncertainties over the future of the community conservation model. In particular, this relates to a commitment to nature conservancy norms and values that have traditionally defined access to and use of communally held resources. Changes in attitudes and aspirations at the local level may explain the drastic appetite for the commodification and commercial exploitation of forests. For example, youth aspire to have greater control of their present and future economic situation due to changes in the patrilineal organization in which parents can no longer guarantee inheritance to their sons. As a result, many youths are motivated to engage in activities that guarantee them quick money to build their own families irrespective of the risks involved in these activities and the danger they cause to communally-owned resources. 
The current demand for forestry commodities and the existing legal and institutional frameworks in many African countries suggest that markets and actors will change even more in favour of organized crime in the future. Indeed, the existence of legal markets for wildlife and forestry commodities fuels illegitimate trade and increases poaching and illegal logging. This has led to a call to ban the legal trade in ivory, ${ }^{17}$ but the debate during the 18th wildlife trade summit in Geneva elicited strong reactions, particularly from SADC member states. ${ }^{18}$ There is a high possibility that debates around the commercial exploitation of forests may follow a similar trajectory in the future.

\section{References}

Arun Kumar, A. N., G. Joshi and H. Ram. 2012. "Sandalwood: History, uses, present status, and the future." Current Science, 103, 12: 1408-1416.

Bussmann, R. W. 1996. "Destruction and management of Mount Kenya's forests." AмBIO, A Journal of the Human Environment, 25, 5: 314-317.

Cerutti, P. O. 2020. A traded tree: What rosewood means for Africa. Trade for Development News. https://trade4devnews.enhancedif.org/en/op-ed/traded-tree-whatrosewood-means-africa

Cerutti, P. O., D. Gumbo, K. Moombe, G. Schoneveld, R. Nasi, N. Bourland and X. Weng. 2018. Informality, global capital, rural development and the environment: Mukula (rosewood) trade between China and Zambia. London/Lusaka: IIED/CIFOR.

Challender, D and D. MacMillan. 2014. "Poaching is more than an enforcement problem." Conservation Letters, 7, 5: 484-494.

Coutu, A. N., J. Lee-Thorp, M. J. Collins, P. J. Lane. 2016. "Mapping the elephants of the 19th century East African ivory trade with a multi-isotope approach." PLoS ONE, 11, 10: eo1636o6. Dor: 10.1371/journal.pone.01636o6.

Duffy, R., F. St John, B. Büscher and D. Brockington. 2015. "The militarization of antipoaching: Undermining long term goals?" Environmental Conservation, 42, 4: 345348. DOI: 10.1017/So37689291500o119.

Elhiraika, A. B., A. K. Mukungu and W. Nyoike (Eds). 2015. Regional integration and policy challenges in Africa. London: Palgrave Macmillan.

European Commission. 2013. Timber trade flows within, to and from eastern and southern African countries. Project 2011/279408, October, HTSPE Limited.

\footnotetext{
17 https://www.reuters.com/article/us-wildlife-cites-elephants-idUSKCN122oOE; https:// www.worldwildlife.org/initiatives/stopping-elephant-ivory-demand.

18 https://www.nationalgeographic.com/animals/2019/o8/elephant-ivory-trade-at-cites/.
} 
FAO (Food and Agricultural Organization of the United Nations). 2020. Global forest resources assessment 2020: Key findings. Rome: FAO. DOI: 10.4060/ca8753en.

Gibson, C. 1999. Politicians and poachers: The political economy of wildlife policy in Africa. Cambridge: Cambridge University Press.

Goncalves, P., M. Panjer, T. S. Greenberg and W. B. Magrath. 2012. Justice for forests: Improving criminal justice efforts to combat illegal logging. Washington: The World Bank.

Harrison M., D. Roe, J. Baker, G. Mwedde, H. Travers, A. J. Plumptre, A. Rwetsiba and E. J. Milner-Gulland. 2015. Wildlife crime: A review of the evidence on drivers and impacts in Uganda. London: IIED. http://pubs.iied.org/17576IIED.

Hayman, G. and D. Brack. 2002. International environmental crime: The nature and control of environmental black markets. London: Royal Institute of International Affairs.

Kamweti D., D. Osiro and D. A. Mwiturubani. 2009. Nature and extent of environmental crime in Kenya. Nairobi: Institute for Security Studies.

Kioko E. M. (forthcoming). “Commodifying East Africa's sandalwood: Organised crime and community participation in the transnational smuggling of an endangered plant." In Commodifying the 'wild': Conservation, markets and the environment in southern and eastern Africa, edited by M. Bollig, S. Lendelwo, A. Mosimane and R. Nghitevelekwa. Woodbridge: Boydell \& Brewer.

Kleinschmit, D., S. Mansourian, C. Wildburger and A. Purret (Eds). 2016. "Illegal logging and related timber trade - dimensions, drivers, impacts and responses. A global scientific rapid response assessment report." IUFRO World Series, 35:1-148.

Lukumbuzya, K. and C. Sianga. 2017. Overview of the timber trade in East and southern Africa: National perspectives and regional trade linkages. Cambridge, UK:Trade Records Analysis of Flora and Fauna in Commerce.

Maguire, T. and C. Haenlein. 2015. An illusion of complicity terrorism and the illegal ivory trade in East Africa. London: Royal United Services Institute for Defence and Security Studies.

Makame, A. 2012. "The East African integration: Achievement and challenges." GREAT Insights, $1,6$.

Müller, D. and J. Mburu. 20o9. "Forecasting hotspots of forest clearing in Kakamega Forest, western Kenya." Forest Ecology and Management, 257, 3: 968-977.

Mwang'ingo, P, Z. Teklehaimanot, J. Hall and L. Lulandala. 2003. "African sandalwood (Osyris lanceolata): Resource assessment and quality variation among populations in Tanzania." Southern African Forestry Journal, 199, 1: 77-88.

Nellemann, C. and Interpol. (Eds). 2012. Green carbon, black trade: Illegal logging, tax fraud and laundering in the world's tropical forests. Nairobi/Washington: UNEP/ Interpol Environmental Crime Programme.

Nellemann, C., R. Henriksen, A. Kreilhuber, D. Stewart, M. Kotsovou, P. Raxter, E. Mrema and S. Barrat. (Eds). 2016. The rise of environmental crime: A growing threat to natural resources peace, development and security. Nairobi: UNEP. 
Nott, K., A. Nott and D. Newton. 2020. A critical assessment of the economic and environmental sustainability of the Namibian indigenous forest/timber industry with reference to Zambiaand Angola. Pretoria: Trade Records Analysis of Flora and Fauna in Commerce.

Ong S. and E. Carver. 2019. The rosewood trade: An illicit trail from forest to furniture. New Haven: Yale School of the Environment. https://e36o.yale.edu/features/therosewood-trade-the-illicit-trail-from-forest-to-furniture.

Peluso, N. L. 1991. "The history of state forest management in colonial Java." Forest \& Conservation History, 35, 2: 65-75.

Redford, K. 1992. "The empty forest." BioScience, 42, 6: 412-422.

Sloan S. and J. A. Sayer. 2015. "Forest Resources Assessment of 2015 shows positive global trends but forest loss and degradation persist in poor tropical countries." Forest Ecology and Management, 352: 134-145.

Sola, P. 2011. Forest law enforcement and governance and trade in the southern African development community. African Forest Forum, working paper series 1, 9: 51 .

Steinhart, E. I. 2006. Black poachers, white hunters: A social history of hunting in colonial Kenya. Oxford: James Currey.

Titeca, K. 2019. "Illegal ivory trade as transnational organized crime? An empirical study into ivory traders in Uganda." The British Journal of Criminology, 59, 1: 24-44. DOI: 10.1093/bjc/azyoog.

UNODC. 2009. Organised crime and trafficking in eastern Africa. A discussion paper. Nairobi: United Nations Office on Drugs and Crime. https://www.unodc.org/documents/easternafrica/regional-ministerial-meeting/Organised_Crime_and_Trafficking_in_Eastern_Africa_Discussion_Paper.pdf.

UNODC. 2020. World wildlife crime report: Trafficking in protected species. Vienna: United Nations Office on Drugs and Crime. https://www.unodc.org/documents/ data-and-analysis/wildlife/2020/World_Wildlife_Report_2020_9July.pdf.

Varun V., T. Ewing and J. Miller. 2014. Out of Africa: Mapping the global trade in illicit elephant ivory. Silver Spring, MD: Born Free USA.

Weru, S. 2016. Wildlife protection and trafficking assessment in Kenya:Drivers and trends of transnational wildlife crime in Kenya and its role as a transit point for trafficked species in East Africa. Cambridge, UK: Trade Records Analysis of Flora and Fauna in Commerce.

World Bank. 2016. Analysis of international funding to tackle illegal wildlife trade. Washington: World Bank.

World Bank. 2018. Tool and resources to combat illegal wildlife trade. Washington: The World Bank.

World Bank. 2019. Illegal logging, fishing, and wildlife trade: The costs and how to combat it. Washington: World Bank. 